удК 342.9

DOI https://doi.org/10.32837/apdp.v0i87.2820

A. В. Чуб

\title{
ІСТОРИКО-ПРАВОВА ХАРАКТЕРИСТИКА СТАНОВЛЕННЯ КОНЦЕПЦІЇ СУБ’СКТИВНИХ ПУБЛІЧНИХ ПРАВ
}

Постановка проблеми. Процеси демократизації та самостійної активності громадянського суспільства, необхідні для відповідного рівня суспільного розвитку, значним чином відстають від аналогічних у розвинених країнах, що зумовлено успадкованими з радянських часів традиціями державоцентризму. Аспекти, які залишилися для багатьох держав у давньому минулому - формування демократичних підвалин функціонування державних органів, переніс акцентів з безпосереднього управління як прояву влади на допоміжні, сервісні функції держави, визначення реалізації та захисту прав, свобод та інтересів особи метою існування держави - в українському адміністративно-правовому полі лише віднедавна стали об'єктом уваги науковців та практиків. Відліковим моментом нашого аналізу вибраний період на зламі XIX - XX століть, коли в наукових колах європейських правознавців виникли жваві дискусії навколо суб'єктивних прав. Вагомий внесок у становлення теорії суб'єктивних прав зробили представники континентальної Європи, особливо німецькі дослідники.

Стан наукової розробки проблеми. Проблематика суб'єктивних прав, у тому числі суб'єктивних публічних, була об'єктом наукового аналізу в працях таких видатних зарубіжних учених, як Б. Віндшайд, К. Гербер, Г. Дернбург, Л. Дюгі, Г. Еллінек, Р. Сринг, І. Колер, К. Лемайєр, Д. Майорана, Г. Мейєр, О. Мейєр, Ф. Регельсбергер, С. Романо, Й. Ульбрих тощо, які й заклали підвалини для ї̈ подальшого теоретичного розвитку. Варто виділити наукові розробки таких вчених, як В.Б. Авер'янов, Ю.П. Битяк, В.І. Васильєва, О.В. Гончарук, Б.М. Дронів, С.П. Погребняк, Р.В. Сивий, В.М. Селіванов, В.В. Галунько, Р.А. Калюжний, М.П. Кунцевич, Ю.О. Легеза, С.В. Савченко, О.М. Вінник, Є.В. Курінний, В.К. Колпаков, Т.О. Коломоєць, А.Я. Курбатов, С.Т. Гончарук та ін. Однак у дослідженнях представників адміністративної науки відсутнім є комплексне дослідження становлення та розвитку концепції суб'єктивних публічних прав.

Метою дослідження є здійснення характеристики наявних теорій походження суб'єктивних публічних прав.

Виклад основного матеріалу. Хронологічно першими серед дослідників суб'єктивних прав називають представників теорії волі. Одним із перших права приватної особи у відносинах із державою розглянув у другій половині XIX століття Карл фон Гербер у роботі «Публічні права». На думку вченого, який першоосновою права вважав владну волю, у відносинах держави й підданих останнім завжди належить підлегле становище, проте при цьому в приватних осіб залишаються певні «основні» права, над якими держава не владна; при цьому зміст зазначених прав залежав від виставлених державною владою обмежень для влад- 
ного розсуду. Тобто в трактовці Гербера публічні права приватних осіб зводились до довільних можливостей, які з'являлися завдяки добровільним самообмеженням державної влади [1].

Бернхард Віндшайд зосереджував увагу на понятті суб'єктивного права, яке розумів як створений юридичним порядком дозвіл діяти в певний спосіб, наданий державною владою. Як і Гербер, Віндшайд відводив визначальні позиції владі, яка і встановлювала норми об'єктивного права, тобто створювала певний юридичний порядок; суб'єктові в цій теоретичній конструкції відводиться функція вибирати жадану модель поведінки з тих, що дозволені правом. Суб'єктивне право в такому трактуванні мало об'єктивний характер [2].

У свою чергу Генрих Дернбург розглядав суб'єктивні права як такі, що вкорінені в самій особі людини й деяким чином залежать від її соціального статусу від «поваги, якої вдалося добитися людині стосовно своєї особи та майна». При цьому суб'єктивне право визначається як право користуватися життєвими благами, яке надається окремій особі загальною волею [3, с. 100].

Зі свого боку Рудольф фон Єринг вибудовував розуміння суб'єктивних прав, спираючись на засади теорії інтересу. Згідно з думкою дослідника, право як продукт народного життя утворюється внаслідок боротьби між різними елементами цього життя, його метою є встановлення певного порядку співіснування зазначених елементів. Тобто суб’єктивне право - не якась абстрактна ідея, не відображення владної волі, як у концепції Гербера, а інструмент реалізації суспільних інтересів різних соціальних елементів. У цьому світлі суб'єктивне право визначається автором як «юридично захищений інтерес».

У суб’єктивному праві, вважає Єринг, потрібно розрізняти два моменти: субстанціональний, або матеріальний, в якому виражається мета права, тобто користь, вигода, яку здобувають за допомогою права, і формальний момент, який стосовно цієї мети виступає як засіб досягнення. Перший момент правознавець образно називає ядром, а другий - шкаралупою, що його закриває. Цей аспект надалі багаторазово піддавався критиці з боку теоретиків-правознавців. На їхню думку, розуміння суб'єктивного права як юридично захищеного інтересу і матеріально-формальна модель цього права не збігаються в тому, що інтерес стосується виключно «ядра», а «шкаралупа» залишається забутою, тоді як саме у формальній забезпеченості інтересів полягає юридична сторона суб’єктивного права. Інтерес же являє собою лише мету, а не суть права [4].

У межах теорії інтересу розглядав суб'єктивні права (і можливість їх захисту) і Карл Лемайєр. Його погляди стосовно суб'єктивних публічних прав спиралися на глибокий історико-правовий аналіз еволюції відносин між державою та окремою особою, здійснений ним у праці «Адміністративна юстиція: поняття охорони суб'єктивних публічних прав у зв'язку з розвитком поглядів щодо держави» [5]. Розглядаючи великий масив історичних фактів, дослідник упевнено доводить існування традиції беззахисності особи перед свавіллям державної влади, притаманні давнім країнам; права індивіда закінчували своє існування там, де виступала держава. Аналізуючи історію інституту адміністративної юстиції як еволюцію захисту сфери прав окремої особи від держави, Лемайєр підкреслює роль незалежності 
судової влади від органів державного управління як юридичної гарантії існування і збереження суб'єктивних прав.

Цікавий внесок у теоретико-методологічні розробки зробив австрійський правник Едмунд Бернацик. Розмірковуючи про взаємні відносини між суб'єктами права та адміністративними органами, автор виділяє три типові ситуації, коли ці відносини відбуваються, та засади для їх виникнення:

1) за умови наявності юридичного інтересу - якщо суб'єкт має кваліфікований юридичний інтерес, щодо якого орган адміністрації зобов'язаний виявити його законність і врахувати його, якщо це можливо (а якщо ні, то повинен виправдати відмову);

2) за умови наявності фактичного інтересу - якщо суб'єкт господарювання в нинішній чи майбутній ситуації отримає пряму користь у результаті дій чи бездіяльності органу публічної влади;

3) за умови наявності публічного суб'єктивного права - якщо суб'єкт звертається до адміністративного суду з позовом щодо вимоги від органу публічної влади конкретних дій (або утримання від певних дій), які він юридично зобов'язаний виконувати (утримуватися) відповідно до свого призначення [6].

Далі цей підхід отримав назву «тріада Бернацика» й активно використовувався в науковій літературі зарубіжних країн з адміністративного права.

Методологічну позицію теорії інтересів поділяв і видатний український правознавець Богдан Кістяківський. Взагалі, суб’єктивні публічні права поряд з участю народу в законодавстві та державному управлінні вчений вважав підвалинами правової держави [7, с. 154]. Обмеження державної влади інтересами особи відбувається за рахунок визнання за людиною суб'єктивних прав у відносинах із тими, хто стоїть вище; таким, за Б.О. Кістяківським, має бути головний принцип правової держави. На думку істориків права, саме Б.О. Кістяківський вперше серед правових теоретиків на теренах Російської імперії заговорив про законне обмеження державної влади правами окремої особистості [8].

Визнаючи індивіда рівноцінною стороною публічних відносин поряд із державою, вчений серед публічних прав, що йому належать, виділяв насамперед права політичні, що стосуються участі в діяльності держави та державних органів. Окрім цього, Б.О. Кістяківський згадував як суб'єктивне публічне право так зване «право на гідне людське існування», що фактично являло собою сукупність декількох прав: права на невтручання держави в особисте життя, права на труд, права на розвиток власних здатностей, право на учать у матеріальних та духовних благах тощо. Аналізуючи сучасний йому стан речей, дослідник зауважував, що законодавчого забезпечення на той момент дістали лише суб'єктивні публічні права на юридичний захист індивіда з боку держави через суд [8, с. 24-28].

Розглядаючи теорію суб'єктивних публічних прав, не можна обійти увагою напрацювання відомого правознавця Георга Еллінека, які в історії правових учень називають «змішаною теорією волі та інтересу» [9, с. 20]. Виходячи, як і попередньо цитовані вчені, з тези про об'єктивний характер публічного права, Еллінек визначає його як право, що регулює відносини між державою та їі членами. При цьому через те, що «не існує влади, яка могла б гарантувати однакову цінність 
вимог особи владної та підлеглої» [10], на перший погляд, держава як «колективна особа» виглядає єдиним суб’єктом публічного права. Спростовуючи цю тезу, Еллінек доходить висновку, що держава володіє правами лише в тому разі, якщо їй протистоять інші особи: і та сторона, що має владу, і та, що владі підкорюється, мають взаємні права та обов' язки [10].

Іншими словами, в контексті цієї концепції суб'єктами публічних прав можуть бути як держава, так й індивіди, що створюють їі субстрат. При цьому публічні права індивідів утворюються завдяки самообмежуванню державою власних публічних прав; це самообмеження, на думку вченого, відбувається негативним або позитивним шляхом. У першому випадку держава визнає певну сферу життя індивіда принципово вільною від владного втручання, обмежуючи державні домагання. Другий (позитивний) шлях полягає в тому, що держава надає підлеглим правову можливість пред'являти певні домагання стосовно державних послуг. Крім того, держава наділяє певне коло індивідів здатністю діяти в інтересах держави, виражаючи у своїх діях волю держави. Тобто йдеться про три особливі правові стани або статуси індивіда як члена певної держави: негативний, позитивний і активний. Негативний статус є для індивіда сферою свободи від держави. Позитивний статус втілюється у правовій здатності індивіда висувати домагання до держави. Активний статус, або статус активного громадянства, полягає у правовій здатності індивіда діяти для держави. Самі собою зазначені статуси, вважав Еллінек, ще не були правами: це тільки різні становища індивіда стосовно держави. Але в кожному разі, коли на певному статусі грунтується правове домагання, статус починає поєднуватися із суб'єктивними публічними правами [1].

Таким чином, у концепції суб'єктивних публічних прав Г. Еллінека акцентовано увагу на взаємних правах і обов'язках держави і громадянина як обов'язковій умові існування публічного права. У найбільш загальному вигляді сукупність суб'єктивних публічних прав, за Еллінеком, складається з права індивідів бути вільними від державних домагань у певних сферах приватного життя; права отримувати й вимагати отримання від держави певних послуг; права брати участь у діяльності держави.

Схожої теоретико-методологічної позиції дотримувався і Фердинанд Регельсбергер. Намагаючись розділити сфери життєдіяльності соціуму як галузі застосування публічного або приватного права, вчений акцентував на тому, що критерієм для цього розподілу виступає характер правовідносин. Як у публічних, так і у приватних правових відносинах можуть брати участь держава, окремі соціальні спільноти, громадяни; якщо жодна зі сторін правовідношення не виступає носієм влади, що має право наказувати, це правовідношення належить до приватного права, і навпаки, якщо одна зі сторін - держава, спільнота чи громадянин - наділена правом наказувати іншій, маємо справу з публічними відносинами [11].

Як із приватних, так і з публічних правовідносин, вважає Регельсбергер, випливають суб'єктивні права. Суб'єктивні публічні права дослідник розглядав крізь призму суб'єктивних інтересів; при цьому само суб'єктивне право не слугує метою діяльності, а являє собою лише засіб досягнення мети. Іншими словами, суб’єктивне право, за Регельсбергером, вміщує повноваження для здійснення дій, 
що слугують досягненню суб'єктом його мети, за умови наявності волі для задоволення інтересу в досягненні мети [11].

На загальному тлі теоретизування щодо суб'єктивних прав досить оригінальною виглядає концепція солідаризму, запропонована Леоном Дюгі, який піддає сумніву можливість існування «суб'єктивних прав» як феномена. На думку правознавця, суб'єктивне право являє собою виключно «метафізичне уявлення»; у правовому аспекті може йтися лише про суб'єктивні обов'язки, якими на індивіда покладається завдання виконати певне соціально важливе призначення, для чого він має виконати певні дії, визначені об'єктивним правом. Іншими словами, Дюгі постулює об'єктивність як визначальну характеристику права, за суб'єктами залишаючи лише приписані об'єктивним правом юридичні становища та відповідні цим статусам моделі поведінки. При цьому, що важливо, «суб’єктивне юридичне становище» в розумінні Дюгі (як сукупність юридичних обов'язків і відповідних їм можливостей) досить тісно корелює із «суб'єктивними правами», тобто заперечення вченим суб'єктивних прав є скоріше номінальним: це «протест проти слова, а не проти суті, що ним позначається» [4].

Нормативна теорія суб'єктивних публічних прав віднайшла своє відображення у працях Ганса Кельзена. У своїй концепції, яку він називав «чисте вчення про право», пропонувалося розуміння правопорядку не як сукупності правових норм, а як багаторівневої системи створення й застосування права. Як концептуальна основа цього вчення виступає ідея про здатність права створювати й нищити себе через самореферентну структуру зв'язків між правовими нормами. У такій теоретичній перспективі створення права являє собою послідовну індивідуалізацію й конкретизацію правових норм: «загальні правові норми» (законодавчі приписи) конкретизують свій зміст стосовно окремих ситуацій через «індивідуальні правові норми» (судові й правозастосовні акти), через акти використання права [12, с. 175].

Висновок. Таким чином, розглянувши головні постулати різних теорій, в межах яких відбувалося становлення концепту суб'єктивних публічних прав, можна дійти таких висновків. Серед запропонованих дефініцій суб'єктивних публічних прав більшість будується на визнанні визначальними їхніми ознаками певних не правових, а психологічних феноменів: волі, інтересу, потенційної активності. Єдиний виняток із цього являє собою концепція Г. Кельзена, який зосередив увагу на нормативно-правовому складнику суб'єктивних публічних прав. Слід підкреслити, що всі названі ознаки - воля, інтерес, готовність діяти та нормативно-правова визначеність - можуть рівною мірою вважатися базовими для розуміння категорії суб'єктивних публічних прав. Саме теоретичні спроби поєднати в одному визначенні ці характеристики для якнайповнішого відображення суті досліджуваного об’єкта окреслюють подальше становлення концепції суб'єктивних публічних прав.

\section{Jimepamypa}

1. Папа Д.М. Становлення наукових поглядів про суб'єктивні публічні права приватних осіб у вітчизняній правовій науці. Форум права. 2009. № 1. С. 415-419. URL: http://nbuv.gov.ua/UJRN/ FP_index.htm_2009_1_59.

2. Михайлов A. Субъективное право: размышления теоретика. Право: блог. URL: https://blog.pravo.ru/blog/5906.html. 
3. Дернбург Г. Пандекты: Общая часть / пер. с нем. Г. Фон Рехенберг ; под ред. : П. Соколовского. Москва : Унив. тип., 1906. 481 с.

4. Шершеневич Г.Ф. Общая теория права. Москва : Изд-е Бр. Башмаковых, 1910. T. III-IV. URL: https://studfile.net/preview/429026.

5. Лемайер К. Административная юстиция: понятие охраны субъективных публичных прав в связи с развитием воззрений на государство ; перевод с немецкого: А.Э. Нольде ; предисл: В. Дерюжинский. С.-Пб. : Сенат. Тип., 1905. 215 с.

6. Koncepcja publicznych praw podmiotowych. Lexplay: doradztwo prawne. URL: https://lexplay.pl/ artykul/prawo_administracyjne/koncepcja_publicznych_praw_podmiotowych1.

7. Кистяковский Б.А. Государство правовое и социалистическое. Вопросы философии. 1990. № 6. C. 141-159.

8. Крамарук С.В. Культура права в концепте социального либерализма Б.А. Кистяковского. Философия права. 2007. С. 24-28.

9. Зеленцов А.Б. Субъективное публичное право : учеб. пособие. Москва : Российский университет дружбы народов, 2012.148 с.

10. Еллинек Г. Система субъективных публичных прав / пер. со 2-го нем. изд-я. под ред. А.А. Рождественского. С.-Петербург ; Москва : Изд-во Освобождение, 1913. URL: https://viewer.rusneb.ru/ru/ 000199_000009_004014568?page $=1 \&$ rotate $=0 \&$ theme $=$ white

11. Регельсбергер Ф. Общее учение о праве / пер. с нем. И.А. Базанова ; под ред. проф. Ю.С. Гамбарова. Москва : Типография И.Д. Сытина, 1897. 296 c. URL: https://viewer.rusneb.ru/ru/000199_00 0009_003680355? page $=245 \&$ rotate $=0 \&$ theme $=$ white.

12. Антонов М.В. Об основных элементах чистого учения о праве Ганса Кельзена. Труды Института государства и права Российской академии наук. 2013. № 4. С. 172-195.

\section{Анотація}

Чуб А. В. Історико-правова характеристика становлення концепції суб’єктивних публічних прав. - Стаття.

У науковій статті визначено особливості становлення та розвитку концепції суб'єктивних публічних прав. Визначено, що хронологічно першими серед дослідників суб'єктивних прав називають представників теорії волі. Встановлено, що одним із перших права приватної особи у відносинах із державою розглянув у другій половині XIX століття Карл фон Гербер у роботі «Публічні права».

Метою дослідження є здійснення характеристики теорій суб'єктивних публічних прав приватної особи. Визначено, що у взаємних відносинах між суб'єктами права та адміністративними органами автор виділяє три типові ситуації, коли ці відносини відбуваються, та засади для їх виникнення: за умови наявності юридичного інтересу - якщо суб’єкт має кваліфікований юридичний інтерес, щодо якого орган адміністрації зобов'язаний виявити його законність і врахувати його, якщо це можливо (а якщо ні, то повинен виправдати відмову); за умови наявності фактичного інтересу - якщо суб’єкт господарювання в нинішній чи майбутній ситуації отримає пряму користь у результаті дій чи бездіяльності органу публічної влади; за умови наявності публічного суб'єктивного права - якщо суб'єкт звертається до адміністративного суду з позовом щодо вимоги від органу публічної влади конкретних дій (або утримання від певних дій), які він юридично зобов'язаний діяти виконувати (утриматися) відповідно до свого призначення. Як висновок обгрунтовано, що загальнотеоретичний підхід до визначення категорії «суб'єктивних публічних прав» будується на визнанні визначальними їхніми ознаками певних не правових, а психологічних феноменів: волі, інтересу, потенційної активності. При цьому підкреслено, що винятковий підхід до розуміння категорії суб’єктивних публічних прав визначено в концепції Г. Кельзена, який зосередив увагу на нормативно-правовому складнику суб’єктивних публічних прав.

Ключові слова: історико-правова характеристика, суб'єктивні публічні права, приватна особа, становлення, нормативістська теорія, теорія волі. 


\section{Summary}

Chub $A$. V. Historical and legal characteristics of the formation of the concept of subjective public rights. - Article.

The scientific article identifies the features of the formation and development of the concept of subjective public rights. It is determined that chronologically the first among the researchers of subjective rights are the representatives of the theory of will. It is established that one of the first rights of an individual in relations with the state was considered in the second half of the XIX century by Carl von Gerber in his work "Public Rights". The purpose of this study is to characterize the formation and development of the concept of subjective public rights. It is determined that the mutual relations between subjects of law and administrative bodies, the author identifies three typical situations when these relations occur, and the principles for their occurrence: provided there is a legal interest - if the subject has a qualified legal interest in which the administrative body is obliged to identify its legality and take it into account, if possible (and if not, must justify the refusal); provided that there is a factual interest - if the business entity in the current or future situation will receive direct benefits as a result of actions or inaction of a public authority; subject to the existence of a public subjective right - if the subject applies to the administrative court with a claim for a requirement from a public authority of specific actions (or refrain from certain actions), which he is legally obliged to perform (withhold) in accordance with its purpose. As a conclusion, it is substantiated that the general theoretical approach to defining the category of "subjective public rights" is based on the recognition of their defining features of certain not legal but psychological phenomena: will, interest, potential activity. It is emphasized that an exceptional approach to understanding the category of "subjective public rights" is defined in the concept of G. Kelzen, who focused on the legal component of subjective public rights.

Key words: historical and legal characteristics, subjective public rights, individual, formation, normative theory, theory of will. 